Nutritive composition of red tilapia reared ... (Raden Roro Sri Pudji Sinarni Dewi)

\title{
NUTRITIVE COMPOSITION OF RED TILAPIA REARED IN FRESHWATER AND BRACKISHWATER
}

\author{
Raden Roro Sri Pudji Sinarni Dewi\#, Priadi Setyawan, Evi Tahapari, \\ Adam Robisalmi, and Nunuk Listiyowati \\ Research Institute for Fish Breeding, Sukamandi, West Java
}

(Received 30 November 2011 ; Accepted 30 April 2012)

\begin{abstract}
The aim of this research was to investigate the nutritive composition (especially fatty acids) in red tilapia that was reared in freshwater and brackishwater. The fatty acid contents were determined by gas chromatography. The fatty acids profile were $\omega$ - 3 (linolenic acid, eicosapentaenoic acid/EPA, docosahexaenoic acid/DHA), $\omega$ - 6 (linoleic acid, arachidonic acid/AA), and $\omega$ - 9 (oleic acid). Red tilapia samples were obtained from Research Institute for Fish Breeding, Sukamandi, West Java (freshwater ponds) and Congot, Yogyakarta (brackishwater ponds; salinity 20 ppt). In this research, red tilapia reared in different ecosystems showed different fatty acid profiles. Red tilapia inhabiting brackishwater ecosystem has EPA $(0.26 \pm 0.05 \%)$, DHA $(3.42 \pm 0.26 \%$, and linoleic acid (17.20 $\pm 0.56 \%$ ) content higher than freshwater ecosystem (EPA $=0 \%$ $\mathrm{DHA}=0.67 \pm 0.44 \%$ linoleic acid $=9.08 \pm 4.76 \%$, except for linolenic acid $(0.30 \pm 0.15 \%$ vs $0.25 \pm 0.10 \%)$, arachidonic acid $(0.77 \pm 0.39 \%$ vs $0.93 \pm 0.13 \%)$ and oleic acid $(38.67 \pm 2.58 \%$ vs $37.44 \pm 0.74 \%$ ). The ratio of $\omega-6 / \omega-3$ in red tilapia inhabiting freshwater ecosystem was about $11 / 1$. The culture tilapia in brackishwater ecosystem decrease $\omega-6 / \omega-3$ ratio $(4.5: 1)$. So that for human health, it will be better to consume brackishwater red tilapia than freshwater red tilapia.
\end{abstract}

KEYWORDS: nutritive composition, fatty acid, red tilapia, freshwater, brackishwater

\section{INTRODUCTION}

Fish is an important source of food for mankind all over the world from the times immemorial. Fish is a very important source of aquatic animal protein in the diets of human being. The important of fish as source of high quality, balanced and easily digestible protein, vitamins and polyunsaturated fatty acids is well understood now (Ravichandran et al., 2011). Fish having energy deposit in the form of lipids will rely on this. Lipids occur in the fish muscle, adipose and liver. The fishes offered as a dietary supplement to the farming pigs has considerably increased their weight and meat yield (Ojewola \&Annah, 2006). The consumption of fish and fish product is recommended as a means of preventing cardiovascular and other diseases and has greatly increased over recent decades in many European countries (Cahu et al., 2004). Besides this fishes are good sources which posses immense antimicrobial peptide in defending against dreadful human pathogens (Ravichandran et al., 2010).

It has been reported that factors such as feed composition, environment, fish size and genetic traits all have an impact on the compo-

\# Corresponding author. Research Institute for Fish Breeding JI. Raya 2 Sukamandi, Subang 41256, West Java, Indonesia. Telp.: +62 260520500 E-mail address: wiewie_thea@yahoo.com 
sition and quality of the cultured fish. Habitat has an impact on the biochemical composition of fishes especially fatty acids (Ravichandran et al., 2011). The existing inter and intra species variability in the composition of fatty acids of fish lipids (and of the specific PUFA/ polyunsaturated fatty acid in particular) is usually explained by the existence of a large number of external factors (environment, culturing method, tropic effects) and internal factors (fish species, feeding regime and digestion, life cycle stage, quantitative and qualitative characteristics of lipids- triacyglycerols, phospholipids and their topographical origin dorsal and ventral part of muscle tissue) (Ugoala et al., 2008).

Marine ecology comprises the ecology of the oceans with their shores and estuaries. The nonliving, or abiotic, materials in a marine ecosystem cycle comprise not only a variety of water-soluble inorganic nutrient salts (nitrates, phosphates, sulphates of $\mathrm{Ca}, \mathrm{Na}, \mathrm{K}$, and dissolved gases) but also organic compounds (amino acids, vitamins, and growth substances) (Ugoala et al., 2008).

Freshwater habitats are divided into a lenitic or basin series, such as lakes, reservoirs, ponds and bogs, and a lotic or channel series, such as rivers, streams, brooks, springs, and groundwater. The lotic series is distinguished by a continual flow of water in one direction. The energy of freshwater ecosystems is derived mainly from photosynthesis accompanied by the algae suspended in the water and by the higher plants and algae growing on or in the bottom. A variable proportion of the total energy available is derived from allochthonous organic matter, such as leaves and pollen, produced by terrestrial communities (Ugoala et al., 2008).

In this research, we investigate the influence of different ecosystem in red tilapia nutritive composition. Red tilapia were reared in freshwater ecosystem and brackishwater ecosystem. The nutritive composition, especially fatty acids, was measured in meat fish.

\section{MATERIALS AND METHODS}

\section{Sample Collection and Preparation}

Red tilapia, weight $300 \pm 50 \mathrm{~g}$, were collected from Research Institute for Fish Breeding (freshwater habitat) and Congot Yogyakarta (Brackishwater habitat, salinity \pm 20 ppt). Fishes were weighed, deheaded, eviscerated and cleaned prior to freezing. An attempt to obtain a homogeneous sample from each species, their flesh were removed from their backbones, skin, minced, blended and immediately extracted. Proximate composition measurement was done at Research Center for Marine and Fisheries Product Processing and Biotechnology. Fatty acid compositions were measured at PT Saraswanti Indo Genetech, Bogor.

\section{Protein Content}

Protein content was measured from $10 \mathrm{~g}$ of flesh. The total protein content was performed with Kjeltec 2300 (FOSS) machine. The total protein content of the fish was estimated by total nitrogen methods. Nitrogen content was calculated by stoichiometry and protein content was estimated by multiply nitrogen content with conversion factor.

\section{Lipid Content}

Lipid extractions were carried out on minced fish samples ( $2 \mathrm{~g}$ each). $150 \mathrm{~mL}$ of chloroform was used to separate lipid from sample. A total of three repetitions were performed per sample. The solvent mixtures were concentrated in vaccuo using a rotary evaporator maintained at $60^{\circ} \mathrm{C}$ for 8 hours and the extracts were stored in sample vial respectively. Lipid content was measured by gravimetric method.

\section{Moisture Content}

Drying is the method employed for the estimation of the moisture content of the given sample. A known quantity of the sample is taken in a weighed dish and the moisture is removed by heating in a hot air oven. Finally it is cooled in a desicator and weighted. The difference between the weight of the sample before and after drying gives the moisture content and it is usually expressed as percentage (\%) of the weight of the sample.

\section{Ash Content}

Sample was destructed at $550^{\circ} \mathrm{C}$ in furnace for 8 hours. Ash content was measured by gravimetric method.

\section{Fatty Acids Analysis}

The analysis of fatty acids was performed with GC Perkin- Elmer- Clarus- 500 plus MSPerkinElmer- Clarus- 500 (column: Perkin- Elmer HP 5- 
$\mathrm{MS}=60 \mathrm{~m} \times 250 \mu \mathrm{m}$; oven: initial temp $50^{\circ} \mathrm{C}$ for $5 \mathrm{~min}$, ramp $3^{\circ} \mathrm{C} / \mathrm{min}$ to $220^{\circ} \mathrm{C}$; inj $=270^{\circ} \mathrm{C}$; volume $=1 \mu \mathrm{L}$; carrier gas $=\mathrm{He}$; solvent delay $=5$ min; transfer temp $=250^{\circ} \mathrm{C}$; source temp $180^{\circ} \mathrm{C}$ ). The individual constituents showed by GC were identified by comparing their MS with standard compounds of Nist and Willey Libraries.

\section{Plankton Abundance}

Plankton samples were collected from brackishwater and freshwater pond. The samples were collected by filtering $10 \mathrm{~L}$ of water using plankton net made of bolting silk (25 $\mu \mathrm{m}$ mesh size). Plankton identification was conducted at Plankton Laboratory in Research Institute for Fisheries Rehabilitation and Conservation, Jatiluhur, West Java.

Plankton counting was conducted by Lackey Drop Microtransect Counting method. Calculation of the plankton as follows: Number of planktons per $\mathrm{mL}=$ (no. of organism counted in all fields $x$ area of cover slip, $\mathrm{mm} 2$ )/ (area of one macroscopic field, $\mathrm{mm} 2 \times$ no. of field counted $x$ volume of sample in the cover slip).

\section{RESULTS}

Protein, lipid, moisture, and ash content in red tilapia reared in freshwater and brackishwater ecosystem were almost similar. It seems, ecosystem have no significant effect on proximate composition. Nutritive composition in brackishwater fishes (Lates calcarifer and Mugil cephalus) are: moisture content between $77.6 \% 81.3 \%$ protein content between $18 \% 20 \%$ and lipid content is about $1 \%$ On the other hand, nutritive composition for freshwater fishes (Catla catla and Oreochromis mossambicus) are: moisture content between $77.93 \% 82.7 \%$ protein content between $19 \% 23 \%$ and lipid content is about
$1 \%$ In the present study, proximate nutritive composition are shown in Table 1.

Fatty acids profile analysis also provide information about the essential fatty acids requirements of fish which would aid the compounding of adequate protein- to- fat ratios feed that would balance energy requirements with caloric intake (Ugoala et al., 2009). The total number of fatty acids that are not present varied among the different habitat of red tilapia. The present analyses showed that eicosapentaenoic acid/ EPA (C20:5) were absent in freshwater red tilapia. Brackishwater red tilapia has higher content of $\omega$ - 3 (EPA and DHA) than freshwater red tilapia (Table 2 ).

The content of $\omega-6$ series of the PUFA, especially linoleic acid, in red tilapia inhabiting freshwater ecosystem is lower than in red tilapia inhabiting brackishwater ecosystem (Table 3). Ravichandran et al. (2011) reported that linoleic acid content in fishes inhabiting freshwater and brackishwater ecosystem varied between $0.27 \% 1.07 \%$ and, arachidonic acid in freshwater and brackishwater fishes were about $0.28 \%$

The $\omega$ - 9 fatty acid in red tilapia reared in freshwater ecosystem resembles as that reared in brackishwater ecosystem (Table 4).

Brackishwater and freshwater pond have different plankton composition (Table 5 and 6). Plankton abundance in brackishwater pond was dominated by Calanus. As for freshwater pond, plankton abundance was dominated by Oscillatoria.

\section{DISCUSSION}

All vertebrates, including fish, lack 12 and $15(\omega-3)$ desaturases enzyme and so it cannot form linoleic acid and linolenic acid from oleic acid. Therefore, linoleic acid and linolenic acid

Table 1. Proximate composition in the muscle tissue of edible red tilapia (g/100 g)

\begin{tabular}{lcc}
\hline \multirow{2}{*}{$\begin{array}{c}\text { Nutritive } \\
\text { composition (\%) }\end{array}$} & \multicolumn{2}{c}{ Red tilapia } \\
\cline { 2 - 3 } & Freshwater & Brackishwater \\
\hline Protein & $17.15 \pm 0.11$ & $17.45 \pm 0.77$ \\
Lipid & $0.87 \pm 0.08$ & $0.80 \pm 0.07$ \\
Moisture & $80.88 \pm 0.56$ & $79.84 \pm 0.31$ \\
Ash & $1.28 \pm 0.02$ & $1.36 \pm 0.03$ \\
\hline
\end{tabular}


Indonesian Aquaculture Journal Vol.7 No.1, 2012

Table 2. $\omega$ - 3 fatty acids content in freshwater and brackishwater red tilapias $(\%)$

\begin{tabular}{lcc}
\hline \multirow{2}{*}{ Fatty acids } & \multicolumn{2}{c}{ Red tilapia } \\
\cline { 2 - 3 } & Freshwater & Brackishwater \\
\hline$\omega-3$ & $0.92 \pm 0.35$ & $3.98 \pm 0.08$ \\
Linolenic acid (C 18:3) & $0.25 \pm 0.10$ & $0.30 \pm 0.15$ \\
Eicosapentaenoic acid/ EPA (C 20:5) & 0 & $0.26 \pm 0.05$ \\
Docosahexaenoic acid/ DHA (C 22:6) & $0.67 \pm 0.44$ & $3.42 \pm 0.26$ \\
\hline
\end{tabular}

Table 3. $\omega-6$ fatty acids content in freshwater and brackishwater red tilapias $(\%)$

\begin{tabular}{ccc}
\hline \multirow{2}{*}{ Fatty acids } & \multicolumn{2}{c}{ Red tilapia } \\
\cline { 2 - 3 } & Freshwater & Brackishwater \\
\hline$\omega-6$ & $10.01 \pm 4.88$ & $17.97 \pm 0.30$ \\
Linoleic acid (C 18:2) & $9.08 \pm 4.76$ & $17.20 \pm 0.56$ \\
Arachidonic acid (C 20:4) & $0.93 \pm 0.13$ & $0.77 \pm 0.39$ \\
\hline
\end{tabular}

Table 4. $\omega$ - 9 fatty acids content in freshwater and brackishwater red tilapias $(\%)$

\begin{tabular}{ccc}
\hline \multirow{2}{*}{ Fatty acids } & \multicolumn{2}{c}{ Red tilapia } \\
\cline { 2 - 3 } & Freshwater & Brackishwater \\
\hline$\omega-9$ & $37.44 \pm 0.74$ & $38.67 \pm 2.58$ \\
Oleic acid (C18:1) & $37.44 \pm 0.74$ & $38.67 \pm 2.58$ \\
\hline
\end{tabular}

Table 5. Plankton composition in brackishwater pond

\begin{tabular}{lc}
\hline Genus & Total number of plankton (ind./ L) \\
\hline Phytoplankton & \\
Asterionella & 7,042 \\
Bidulphia & 3,018 \\
Chaetoceros & 3,018 \\
Coscinodiscus & 18,108 \\
Gramatophora & 7,042 \\
Rhizosolenia & 9,054 \\
Thallasiotrix & 3,018 \\
Ceratium & 3,018 \\
\hline Zooplankton & \\
Calanus & 95,570 \\
Acartia & 17,120 \\
\hline
\end{tabular}


Nutritive composition of red tilapia reared ... (Raden Roro Sri Pudji Sinarni Dewi)

Table 6. Plankton composition in freshwater pond

\begin{tabular}{lc}
\hline \multicolumn{1}{c}{ Genus } & Total number of plankton (ind./ L) \\
\hline Phytoplankton & 604 \\
Actinastrum & 604 \\
Aphanocapsa & 5,436 \\
Chlorella & 1,812 \\
Coelastrum & 604 \\
Eudorina & 604 \\
Oocystis & 1,812 \\
Pandorina & 5,436 \\
Pediastrum & 1,812 \\
Scenedesmus & 2,416 \\
Ulotrix & 2,416 \\
Chroococcus & 1,208 \\
Microcystis & 128,652 \\
Oscillatoria & 7,248 \\
Cycotella & 604 \\
Peridinium & 7,248 \\
Euglena & 604 \\
\hline Zooplankton & \\
Fillinia & \\
\hline
\end{tabular}

are essential fatty acids in diets of vertebrates (Tocher, 2003). The tissues of both freshwater and marine fish are generally very rich in C20 and C22 fatty acids, especially EPA and DHA. The pathway biosinthesising EPA and DHA from linolenic acid is present in rainbow trout, AtIantic salmon, Arctic charr, brown trout, zebrafish and carp (Tocher, 2003).

Most animals can synthesize C18: $\omega$ - 9/ oleic acid de novo should not prevent us from considering the possibility that fatty acids of the $\omega$ - 9 series might play just as vital a role in the physiology of some species as do the $\omega-6$ or $\omega$ - 3 series fatty acids (Castell, 1979).

In this research, red tilapia reared in different ecosystem showed different fatty acids profiles. Red tilapia inhabiting brackishwater ecosystem has EPA, DHA and linoleic acid higher than that of freshwater ecosystem, but it is not with linolenic acid, arachidonic acid and oleic acid . EPA was found in brackishwater red tilapia but was not in freshwater red tilapia. There is an inter species variability in the composition of fatty acids of fish lipids (and of the specific polyunsaturated fatty acids in particu- lar). Based on Ugoala et al. (2008) research, the marine species are better in DHA. The freshwater species are in linoleic acid as well as in arachidonic acid contents. The latter fatty acid is a major constituent of membrane lipids (phospholipids) and is the principal precursor by enzymatic action of hormone- like compounds known as eicosanoids including the prostaglandins (prostanoids, isoprostanes, and isofurans). The eicosanoids produced from C20:4n- 6 cause the strongest inflammatory response in humans. Inflammation is one of the body defense mechanisms that reduce the spread of infection.

Based on Tocher (2003) research, fatty acids of C20:5n- 3 (EPA) and C22:6n- 3 (DHA) are very abundant in the marine environment, originating mainly in diatoms and flagellates, respectively, at the base of the food web, where they are transmitted intact via zooplankton to fish. In this research, we found that brackishwater pond was dominated by Calanus, and freshwater pond was dominated by Oscillatoria. Based on some research, brackishwater plankton (ex. Calanus and 
Acartia) have EPA and DHA content higher than freshwater plankton (ex. Chlorella and Oscillatoria) (Table 7). Therefore, marine fish have a luxus EPA and DHA in their natural diets.

In contrast, freshwater plankton have 18:3n3 and 18:2n6 higher than brackishwater plankton (Table 7). The natural prey of many freshwater fish, particularly their invertebrate prey, is not rich in DHA, being rich instead in 18:2n- 6 (linoleic acid), 18:3n- 3 (linolenic acid), and to lesser extent EPA. In marine organism, especially algae, can contain a plethora of PUFA of chain length $\mathrm{C} 16$ (with 2- 4 ethylenic bonds), C18 (with 2- 5 ethylenic bonds), C20 (with 2- 5 ethylenic bonds) and C22 (with 2- 6 ethylenic bonds) (Sargent et al., 1995). These PUFA are generally of the $\omega$ - 3 series, although representative of the $\omega-6$ and, in the case of C16 PUFA, the $n-1, n-4$ and n- 7 series also occur (Ackman, 1989). However, in fish the main PUFA to be considered are C20:4n- 6 (arachidonic acid, AA) and its metabolic precursor 18:2n- 6 (linoleic acid, LA), together with 20:5n- 3 (EPA) and 22:6n3 (DHA) and their metabolic precursor 18:3n- 3 ( $\alpha$ - linoleic acid, LNA) (Tocher, 2003).

Ravichandran et al. (2011) reported that freshwater fishes is more of $\omega$ - 6 series of the PUFA while the marine is more of $\omega$ - 3 series. The prominent $\omega$ - 3 being C22:6 while the C18:2 are for the $\omega$ - 6 series. This may suggest that the dietary essential fatty acids requirements for marine fish for $\omega$ - 3 PUFA may be higher than that of freshwater fish. The nutritional requirement of marine species for long chain PUFA $\omega$ - 3 may not be met by $18: 3 n-3$ due to limited capacity for chain elongation and desaturation (Cowey et al., 1976; Deshimaru et al., 1982). The PUFA $\omega$ - 3 seem to be more potent than $18: 3 n-3$ as sources of essential fatty acids (Takeuchi \& Watanabe, 1977).

The difference between marine and freshwater fish may be due simply to differences in the fatty acid content in the diet or it may be related to a specific requirement in fish related to physiological adaptations to the environment. The phospholipids are generally considered to be structural or functional lipid, being incorporated to a large extent in the membrane structure of cell and subcellular particles. Marine fish seem to require not just $\omega$ - 3 fatty acids but $\omega$ - 3 fatty acids of 20 to 22 carbon- chain length. The role of $\omega$ - 3 fatty acids in membrane permeability may be one of the factors accounting for differences in content of this family of fatty acids between freshwater and marine fish (Castell, 1979).

The ratio of $\omega-6 / \omega$ - 3 in red tilapia inhabiting freshwater ecosystem was about $11 / 1$. The culture of red tilapia in brackishwater ecosystem decrease $\omega-6 / \omega-3$ ratio (4.5:1). Castell (1979) reported that $\omega-6 / \omega-3$ ratios in freshwater fish is higher than marine fish. The same type of difference in the $\omega-6 / \omega$ - 3 ratio between freshwater and seawater is seen when some species of fish migrate from oceans to streams or vice versa. The PUFA ratio of sweet smelt (Plecoglossus altivelis) changed drastically in only one month as they migrate from the sea

Table 7. Fatty acid composition (\%of total fatty acids) of plankton

\begin{tabular}{|c|c|c|c|c|}
\hline \multirow{2}{*}{$\begin{array}{l}\text { Fatty } \\
\text { acid }\end{array}$} & \multicolumn{2}{|c|}{ Brackishwater plankton } & \multicolumn{2}{|c|}{ Freshwater plankton } \\
\hline & $\begin{array}{l}\text { Acartia } \\
\text { centrura }\end{array}$ & $\begin{array}{c}\text { Calanus } \\
\text { hyperboreus }\end{array}$ & Chlorella sp. & Oscillatoria sp. \\
\hline $18: 3 n-3$ & 8.79 & - & 27 & 24.6 \\
\hline $20: 5 n-3$ & 10.07 & 23.1 & - & - \\
\hline $22: 6 n-3$ & 9.61 & 3.2 & - & - \\
\hline $18: 2 n-6$ & 1.07 & 2.2 & 19.8 & 11.4 \\
\hline $20: 4 n-6$ & - & 13.7 & - & - \\
\hline $18: 01 n-9$ & 8.61 & 5.4 & 2.2 & 1.9 \\
\hline Reference & 1 & 2 & 3 & 4 \\
\hline
\end{tabular}

Source:

1. Vengadeshperumal et al. (2010)

3. Dunstan et al. (1992)

2. Richard et al. (1972)

4. Ahlgreen et al. (1990) 
to a freshwater river (Ota \& Takagi, 1977). Even within a single species of fish, the salinity of the water seems to cause a dramatic change in the fatty acid pattern.

In human nutrition fatty acids such as linoleic and linolenic acid are regarded as essential since they cannot be synthesized by the organism. In marine fish, these fatty acids constitute only around $2 \%$ of the total lipids which is a small percentage compared with many vegetable oils. However, fish oils contain other polyunsaturated fatty acids which are essential to prevent skin diseases in the same way as linoleic and arachidonic acid. As member of the linolenic acid family (first double bond in the third position, $\omega$ - 3 counted from the terminal methyl group), they will also have neurological benefits in growing children (Ravichandran et al., 2011). One of this fatty acids, eicosapentaenoic acid (C20:5n- 3), has recently attracted considerable attention because Danish scientists have found this acid high in the diet of a group of Greenland Eskimos virtually free from arteriosclerosis. Investigations in the United Kingdom and elsewhere have documented that eicosapentaenoic acid iln the blood is an extremely potent antithrombotic factor (Simopoulos, 1991).

Even though the fish fat content is comparatively lesser than the beef meat value 16.7\%(Quasem et al., 2009) the DHA and PUFA value is somewhat higher in fishes in the present finding. Several marine fish species are rich in $\omega-3$ polyunsaturated fatty acids (PUFA) such as EPA and DHA. This is attributed to the lipid composition of plankton. There is strong evidence suggesting that consumption of fish containing high levels of these fatty acids is favorable for human health and has a particularly beneficial effect in preventing cardiovascular diseases.

However, freshwater fish species can also serve as a valuable source of essential fatty acids. Compared with marine fish species, freshwater fish contain, in general, higher levels of CIS PUFA but also substantial concentration of EPA and DHA. Moreover, as Harris (1996) has noted, the potential for benefit remains high, since dietary fish oils affect a myriad of potentially atherogenic processes. In addition, the fatty acid composition of freshwater fish species is characterized by high proportion of $\omega$ - 6 PUFA, especially linoleic acid and arachidonic acid. Therefore, the ratio of total $\omega$ - 3 to $\omega$ - 6 fatty acids is much lower for freshwater fish than for marine fish, ranging from 1 to about 4. However, keeping freshwater fishes on diets containing higher amounts of fish oil results in marketable fish with substantial levels of $\omega$ - 3 PUFA (Ravichandran et al., 2011).

Several sources of information suggest that human beings evolved on a diet with a ratio of omega- 6 to omega- 3 essential fatty acids (EFA) of $\sim 1$ whereas in Western diets the ratio is 15/1-16.7/1. Western diets are deficient in omega- 3 fatty acids, and have excessive amounts of omega- 6 fatty acids compared with the diet on which human beings evolved and their genetic patterns were established. Excessive amounts of omega- 6 polyunsaturated fatty acids (PUFA) and a very high omega- 6/ omega- 3 ratio, as is found in today's Western diets, promote the pathogenesis of many diseases, including cardiovascular disease, cancer, and inflammatory and autoimmune diseases, whereas increased levels of omega- 3 PUFA (a lower omega- 6/ omega- 3 ratio), exert suppressive effects. In the secondary prevention of cardiovascular disease, a ratio of 4/ 1 was associated with a $70 \%$ decrease in total mortality. A ratio of 2.5/ 1 reduced rectal cell proliferation in patients with colorectal cancer, whereas a ratio of 4/1 with the same amount of omega- 3 PUFA had no effect. The lower omega- 6/ omega- 3 ratio in women with breast cancer was associated with decreased risk. A ratio of 2-3/ 1 suppressed inflammation in patients with rheumatoid arthritis, and a ratio of 5/ 1 had a beneficial effect on patients with asthma, whereas a ratio of 10/ 1 had adverse consequences. These studies indicate that the optimal ratio may vary with the disease under consideration. This is consistent with the fact that chronic diseases are multigenic and multifactorial. Therefore, it is quite possible that the therapeutic dose of omega- 3 fatty acids will depend on the degree of severity of disease resulting from the genetic predisposition. A lower ratio of omega- 6/ omega- 3 fatty acids is more desirable in reducing the risk of many of the chronic diseases of high prevalence in Western societies, as well as in the developing countries (Simopoulous, 2008). Rearing red tilapia in brackishwater decrease $\omega-6 / \omega-3$ ratio from $11: 1$ to $4.5: 1$. So for human, it will be better to consume brackishwater red tilapia than freshwater red tilapia. 


\section{CONCLUSION}

In the current finding it is concluded that ecosystem affected fatty acid composition. Reared red tilapia cultured in brackishwater containing higher EPA, DHA and linoleic acid content but has a lower $\omega-6 / \omega-3$ ratio than red tilapia freshwater. For human health, it will be better to consume brackishwater red tilapia than freshwater red tilapia.

\section{REFERENCES}

Ackman, R.G. (Eds.). 1989. Marine biogenic lipids, fats and oils. Florida: CRC Press.

Ahlgren, G., Lundstedt, L., Brett, M., and Forsberg, C. 1990. Lipid composition and food quality of some freshwater phytoplankton for cladoceran zooplankters. J. Plankton Res., 12: 809- 818.

Buchtova, H., Smutna, M., Vorlova, L., Svobodova, Z., \& Flajsens, M. 2004. Fatty acid composition of diploid and triploid population of trench (Tinca tinca L). ACTA VET BRNO, 73: 235- 245.

Cahu, C., Salen, P., \& De Lorgeril, M. 2004. Farmed and wild fish in the prevention of cardiovascular disease: Assessing possible differences in lipid nutritional values. Nutr. Meta Cardiovasc Dis., 14: 34- 41.

Castell, J.D. 1979. Review of lipid requirement of finfish. In finfish nutrition and fishfeed technology vol.1. Halver, J.E. and Tiews, K. (Eds.). Proc. World Symp. On Finfish Nutrition and Fishfeed Technology, Hamburg 20- 23 June, 1978. Vol. I. Berlin 1979.

Cowey, C.B., Owen, J.M., Adron, J.W., \& Middleton C. 1976. Studies on the nutrition of marine flatfish. The effect of different dietary FA on the growth and FA composition of turbot (Scopthalmus maximus). British J. Nutr., 36: 479- 486.

Deshimaru, O., Kuroki, K., \&Yone, Y. 1982. Nutritive values of various oils for yellow. Bulletin Jpn. Soc. Sci. Fisheries, 48: 1,155$1,157$.

Dunstan, G.A., Volkman, J.K., Jeffrey, S.W., \& Barret SM. 1992. Biochemical composition of microalgae from the green algal classes chlorophyceae and prasinophyceae. 2. Lipid classes and fatty acids. J. Exp. Mar. Biol. Ecol., 161: 115- 134.

Harris, W.S. 1996. Dietary fish oil and blood lipid. Curr Opin Lipidol, 17: 3- 7.

Ojewola, G.S. \& Annah, S.I. 2006. Nutritive and economic value of Danish fish meal, cray- fish dust meal and shrimp waste meal inclusion in broiler diets. Int. J. Poult. Sci., 5: 390- 394.

Ota, T. \& Takagi, T. 1977. A comparative study on the lipid class composition and fatty acid composition of sweet smelt Plecoglossus altivelis, from marine and freshwater habitat. Bull. Fac. Fish. Hokkaido Univ., 28(1): 47- 56.

Quasem, J.M., Mazahreh, A.S. , \&Al- Shawabkeh, A.F. 2009. Nutritive value of seven varieties of meat products (sausage) produced in Jordan. Pak. J. Nutr., 8: 332- 334.

Ravichandran, S., Kumaravel, K., Rameshkumar, G., \& Ajithkumar, T.T. 2010. Antimicrobial peptides from the marine fishes. Res. J. Immunol., 3: 146- 156.

Ravichandran, S., Kumaravel, K., \& Florence, E.P. 2011. Nutritive composition of some edible fin fishes. Int. J. of Zoo Research, p. 1-11.

Richard, F.L., Hirota, J., Nevenzel, J.C., Sauerheber, R., \& Benson, A.A. 1972. Lipids in the marine environment. Calif. Mar. Res. Comm., 16: 95- 102.

Sargent, J.R., Bell, M.V., \&Henderson, R.J. 1995. Protist as sources of essential ( $n-3)$ polyunsaturated fatty acids for predator development. Eur. J. Protistol., 31: 460- 461.

Simopoulos, A.P. 1991. Omega- 3 fatty acids in health and disease and in growth and development. Am. J. Clin. Nutr., 54: 438463.

Simopoulos, A.P. 2008. The importance of the omega- 6/omega- 3 fatty acid ratio in cardiovascular disease and other chronic diseases. Exp. Biol. Med., 233: 674- 688.

Takeuchi, T. \&Watanabe, T. 1977. Requirement of carp for essential fatty acids. Bulletin Jpn. Soc. Sci. Fisheries, 43: 541- 551.

Tocher, D.R. 2003. Metabolism and function of lipids and fatty acids in teleost fish. Review in Fisheries Sciences, 11(2): 107- 184.

Ugoala, C., Ndukwe, G.I., \& Audu, T.O. 2008. Comparison of fatty acids profile of some freshwater and marine fishes. Internet Journal of Food Safety, 10: 9- 17.

Ugoala, C., Ndukwe, G.I., \& Audu, T.O. 2009. Investigation of the constituent fatty acids of some freshwater fishes common in Nigeria. Braz. J. Aquat. Sci. Technol., 13(1): 65- 70.

Vengadeshperumal, N., Damotharan, P., Rajkumar, M., Perumal, P., Vijayalakshmi, S., 
Nutritive composition of red tilapia reared ... (Raden Roro Sri Pudji Sinarni Dewi)

\& Balasubramanian, T. 2010. Laboratory culture and biochemical characterization of the calanoid copepod, Acartia southwelli
Sewell, 1914 and Acartia centrura Giesbrecht, 1889. Adv. in Biol. Res., 4(2): 97- 107. 